\title{
KOŚCIÓŁ W POLSCE REPRESJONOWANY PRZEZ WLADZE KOMUNISTYCZNE W LATACH 1944-1989
}

Komuniści po rozbiciu opozycji i zbrojnego podziemia rozpoczęli proces sowietyzacji Polski. Cała ich działalność sprowadzała się do kolektywizacji wsi i walki z Kościołem. Już 20 XII 1944 roku w resorcie bezpieczeństwa Polskiego Komitetu Wyzwolenia Narodowego (PKWN) powstała komórka do zwalczania wrogiej agentury wśród duchowieństwa. Kierowniczką Wydziału Departamentu V Ministerstwa Bezpieczeństwa Publicznego (MBP) została Julia Brystygierowa, nazywana „Krwawą Luną”1.

Kościół po zakończeniu II wojny światowej starał się angażować w sprawy kraju, m.in. wzywając Polaków do odbudowy kraju. Zagadnieniem tym zajęli się biskupi na Konferencji Episkopatu na Jasnej Górze (3-4 X 1945), przestrzegając jednocześnie przed bezbożnictwem, sektami i propagandą antychrześcijańską.

* Ks. Józef Dębiński - dr hab. historii, współpracownik Wydziału Politologii i Stosunków Miedzynarodowych UMK w Toruniu.

${ }^{1} \mathrm{R}$. Gryz, Władze partyjno-państwowe $w$ Polsce $w$ walce $z$ duchowieństwem, w: Represje wobec duchowieństwa Kościołów chrześcijańskich $w$ okresie stalinowskim w krajach byłego bloku wschodniego, red. J. Myszora i A. Dziuroka, Katowice 2004, s. 108-110; M. Piotrowski, Ludzie bezpieki $w$ walce z Narodem i Kościołem. Stużba Bezpieczeństwa w Polsce Rzeczpospolitej Ludowej w latach 1944-1978 - Centrala, Lublin 2000, s. 394; H. Dominiczak, Organy bezpieczeństwa PRL w walce z Kościotem katolickim 1944 - 1990 w świetle dokumentów MSW, Warszawa 2000, s. 22; A. Garlicki, $Z$ tajnych archiwów, Warszawa 1993, s. 41-52. Od 1944 roku w ramach Resortu Bezpieczeństwa Publicznego znajdował się Wydział III, a od 1945 roku w ramach Ministerstwa Bezpieczeństwa Publicznego Departament Społeczno-Polityczny, określany jako Departament V; składał się z trzech sekcji, z których pierwsza dotyczyła Obsługi Kościoła Rzymskokatolickiego. Departament miał swoje odpowiedniki w województwach (Wydziały V) i powiatach (Referaty V). Po reorganizacji w 1953 roku MBP utworzono Departament XI, a po likwidacji MBP w 1954 roku i utworzeniu Komitetu do Spraw Bezpieczeństwa Publicznego sprawami Kościoła rzymskokatolickiego zajmował się Departament VI. Na bazie wydzielonego z Departamentu III MSW Wydziału V powstał w 1962 roku Departament IV MSW, odpowiedzialny za politykę wobec Kościoła katolickiego. 
Ważnym był też list papieża Piusa XII z 29 VI 1945 roku zachęcający do podjęcia odbudowy życia gospodarczego i religijnego w Polsce².

Wprawdzie w latach 1944-1947 władze stosowały względnie liberalną politykę wobec Kościoła, co nie wykluczało jednak represji wobec konspiracyjnej działalności duchowieństwa, a nawet skrytobójczych mordów ${ }^{3}$. Aresztowań dokonywano na podstawie podejrzeń lub służbowych decyzji, z reguły bez decyzji prokuratora. Śledztwo prowadzono pod założoną z góry tezę, że podejrzany jest wrogiem klasowym, agentem imperializmu lub też niemieckim kolaborantem. Należy zaznaczyć, że skazując osoby duchowne stosowano różne przepisy prawa karnego $^{4}$. Ludowy Komisariat Spraw Wewnętrznych (NKWD) w Rzeszowie 8 XII 1944 roku aresztował ks. Michała Pilipca, kapelana Armii Krajowej. Po torturach został on zabity strzałem w tył głowy; był prawdopodobnie pierwszym kapłanem ofiarą mordu politycznego w Polsce Ludowej ${ }^{5}$. W 1945 roku w archidiecezji wrocławskiej zamordowano 11 księży, którzy stanęli w obronie gwałconych kobiet ${ }^{6}$.W Kraśniku w diecezji lubelskiej10 III 1945 roku zabity został przez milicjanta Bolesława Bajera rektor kościoła Świętego Ducha i kapelan Narodowych Sił Zbrojnych ks. Stanisław Zieliński ${ }^{7}$, a w nocy z 11/12 maja tegoż roku bojówka aktywistów PPR uprowadziła w Płokach w archidiecezji krakowskiej i zastrzeliła ks. Michała Rapacza ${ }^{8}$. Trzej funkcjonariusze z krakowskiego UB zastrzelili w nocy

${ }^{2}$ B. Kumor, Historia Kościoła, t. 8, Lublin 2001, s.476. Episkopat w liście wielkopostnym w 1946 roku powrócił do tego tematu: „Polska nie może być bezbożna, Polska nie może się wyprzeć przynależności do świata chrześcijańskiego, Polska nie może zdradzić ducha swych dziejów, Polska nie może być komunistyczna, Polska musi pozostać katolicką".

${ }^{3}$ R. Gryz, Wtadze partyjno-państwowe, s. 112. Do połowy 1947 roku w więzieniach przebywało ok. 60 księży. W jednym z poufnych raportów ambasador angielski w Moskwie pisał (23 IV 1945) do Stolicy Apostolskiej: „Nie ma żadnych zakłóceń w publicznych nabożeństwach, a księża nie są nękani".

${ }^{4}$ A. Grześkowiak, Prawo karne instrumentem walki z Kościołem w latach 1944-1956, w: Represje wobec osób duchownych i konsekrowanych w PRL w latach 1944-1989, red. A. Grześkowiak, Lublin 2004, s. 52. Jednym z pierwszych aktów normatywnych był dekret PKWN z 23 IX 1944 roku. Stanowił podstawę do karania śmiercią osób prowadzących działalność polityczną niezgodną $\mathrm{z}$ linią PKWN.

${ }^{5}$ J. Myszor, J. Żurek, Pilipiec Michat (1912-19440, kapłan diecezji przemyskiej, w: Leksykon duchowieństwa represjonowanego w PRL w latach 1945-1989, t. 2, red. J. Myszor, Warszawa 2003, s. 220-221; J. Żurek, W obliczu śmierci. Zabójstwa osób duchownych w powojennej Polsce (19441989), w: Represje wobec osób duchownych, s. 267. Aresztowany pod zarzutem ukrywania drukarni i napadu na posterunek MO w Chiżnem został zamordowany w lasach głogowskich, zwłoki częściowo spalone, porzucono w lesie, nawet ich nie zakopując.

${ }^{6}$ Żurek, W obliczu śmierci, s. 278.

${ }^{7}$ M. Paluch, Zieliński Stanisław (1911-1945), kapłan diecezji lubelskiej, w: Leksykon duchowieństwa represjonowanego w PRL, t. 3, s. 266-268; L. Kuśmierczyk, L. Meresta, Kapelan Narodowych Sit Zbrojnych w latach 1939-1944 ze szczególnym uwzględnieniem Lubelszczyzny, Warszawa 2000, s. 48; Cz. Stępniak, Przebieg śledztwa w sprawie ks. Stanisława Zielińskiego w pracach MRN w latach 1944-1945, „Regionalista”, 1995, nr 3, s. 8-9; T. Żurek, W obliczu śmierci, s. 287.

${ }^{8}$ J. Szarek, Rapacz Michat (1904-1946), kapłan archidiecezji krakowskiej, w: Leksykon duchowieństwa represjonowanego w PRL, t. 1, Warszawa 2002, s. 242-243; J. Szarek, Ksiadz Michat Rapacz - śmieć za wiarę, „Biuletyn Instytutu Pamięci Narodowej”, 4 (2001) s. 40-42. 
z 6/7 września 1946 roku na plebanii w Libiążu ks. Franciszka Flasińskiego9, a 4 VIII 1946 roku aresztowano ks. Zygmunta Jarkiewicza, wikariusza parafii Kiczki, k. Mińska Mazowieckiego za sprzeciwianie się oddawania kontyngentów oraz posiadanie broni palnej; został skazany na karę śmierci, którą w drodze łaski zamieniono na 15 lat wiezienia; zmarł we Wronkach (10 VI 1946) ${ }^{10}$. Z kolei 29 XI 1947 roku ks. Jan Stępień (późniejszy rektor ATK), kapelan AK i członek ZG Stronnictwa Narodowego został czterokrotnie skazany na karę śmierci, decyzją Bieruta zamieniona na 15 lat więzienia ${ }^{11}$. Podobnie 24 grudnia tegoż roku ks. Bolesław Stefański, kapelan Narodowych Sił Zbrojnych został skazany na karę śmierci, zamienioną na dożywotnie więzienie ${ }^{12}$. Pierwszym biskupem aresztowanym 26 IV 1946 roku (na 13 godzin) był sufragan częstochowski Stanisław Czaj$\mathrm{ka}^{13}$. Do połowy 1947 roku w polskich więzieniach przebywało ok. 60 duchownych ${ }^{14}$. Pierwszym kapłanem z diecezji włocławskiej aresztowanym przez UB za wygłoszenie kazania był ks. Jan Więckiewicz, administrator parafii Aleksandrów Kujawski (10 V 1945). W czasie uroczystości Wniebowstąpienia miał powiedzieć, że „wszyscy, którzy jak Hitler walczą z Kościołem, marnie zginą”"15. Pod zarzutem działalności antypaństwowej uwięziono także w marcu 1945 roku kamilinina pracującego w Lipnie o. Antoniego Sołtysiaka ${ }^{16}$, a w następnym roku orionistę, byłego administratora parafii Witowo, ks. Józefa Burzyńskiego ${ }^{17}$.

${ }^{9}$ T. Isakowicz-Zaleski, Księża wobec bezpieki, Kraków 2007, s. 32.

${ }^{10}$ R. Mikołajczak, Jarkiewicz Zygmunt (1901-1949), kapłan archidiecezji warszawskiej, w: Leksykon duchowieństwa represjonowanego w PRL, t. 1, s. 95; M. R. Bombicki, Księża przed sądami specjalnymi 1944-1954, Poznań 1993, s. 47-51.

${ }^{11}$ H. Sieński, Stępień Jan Piotr (1910-1995), rektor ATK, w: Leksykon duchowieństwa represjonowanego $w$ PRL, t. 1, s. 268-270; Informator o osobach skazanych za szpiegostwo $w$ latach 1944-1984, Lublin 1994, s. 335, 400.

12 J. Żurek, Stefański Bolesław (1910-1964), kapłan archidiecezji warszawskiej, w: Leksykon duchowieństwa represjonowanego w PRL, t. 2, s. 271-277; T. Roztworowski, Zaraz po wojnie. Wspomnienia duszpasterza (1945-1956), Paris 1986, s. 185. Oskarżony o kierowanie organizacją pod nazwa Pogotowie Akcji Specjalnej i podżeganie do zabicia wójta w Markach został skazany 23 XII 1946 roku na karę śmierci, zamienioną w 1947 roku na dożywocie; opuścił więzienie w 1954 roku

${ }^{13}$ T. Żarnowiecka-Gryz, Czajka Stanisław (1897-1965), biskup sufragan częstochowski, w: Leksykon duchowieństwa represjonowanego w PRL, t. 2, s. 41-43; A. Dudek, Państwo i Kościót $w$ Polsce 1945-1995, Kraków 1995, s. 9. Po zwolnieniu zastosowano wobec biskupa areszt domowy. Głównym oskarżeniem był ,atak na demokrację”.

${ }^{14}$ Gryz, Władze partyjno-państwowe, s. 112.

${ }^{15}$ A. Poniński, Represje wobec duchowieństwa i sióstr zakonnych $w$ diecezji włocławskiej, w: Represje wobec osób duchownych, s. 339.

${ }^{16}$ Dominiczak, Organy bezpieczeństwa PRL, s. 83. Należał do kapłanów związanych z podziemiem niepodległościowym.

17 A. Poniński, Burzyński Józef (1900-1977), kapłan archidiecezji wrocławskiej, w: Leksykon duchowieństwa represjonowanego w PRL, t. 3, red. J. Myszor, Warszawa 2006, s. 18-20. Powodem aresztowania była rzekoma współpraca $z$ działającą po zakończeniu II wojny światowej w powiecie nieszawskim grupą „Szarego”(Jerzego Gadzinowskiego); zwolniony z aresztu dokładnie rok później. 
Władzom komunistycznym w pierwszych miesiącach istnienia nowej państwowości w stosunkach z Kościołem przyświecały przede wszystkim cele pragmatyczne, stąd m.in. dążenie do uznania ich władzy przez Kościół, nawet nieformalne, gdyż to legitymizowało ich działania wobec narodu. Dlatego w czerwcowej procesji Bożego Ciała w Warszawie w 1945roku uczestniczył Bolesław Bierut, członkowie rządu i generałowie wojska, a w wielu miastach wojewódzkich członkowie lokalnych władz.

Wkrótce jednak doszło do jawnego sporu Episkopatu z władzami państwowymi na skutek wydania 25 IX 1945roku przez Prezydium Krajowej Rady Narodowej dekretu ustanawiającego przymus ślubów cywilnych. Biskupi w tej sprawie wystosowali 7 XII 1945 roku z Jasnej Góry orędzie, w którym bronili nierozerwalności węzła małżeńskiego ${ }^{18}$. Największym posunięciem restrykcyjnym władz było jednak jednostronne zerwanie konkordatu (12 IX 1945) w imię propagandowego hasła „rozdziału Kościoła od państwa”19. Kolejnym powodem sporu była sprawa administracji kościelnej na Ziemiach Zachodnich i Północnych. Prymas Polski na mocy specjalnych uprawnień otrzymanych od Stolicy Apostolskiej mianował dla tych terenów pięciu administratorów apostolskich ${ }^{20}$. Nieporozumienia między komunistycznymi władzami a Kościołem dotyczyły również katechizacji; zgodnie z zarządzeniem ministerstwa oświaty z 27 XII 1945 roku na terenie szkoły nie mogły działać religijne organizacje, takie jak Sodalicja Mariańska i Krucjata Eucharystyczna ${ }^{21}$. W odpowiedzi na poczynania władz Episkopat Polski w specjalnym liście pasterskim z 7 IX 1947 roku skrytykował całą ideologię komunistyczną. W odwecie Biuro Polityczne KC PPR (1 X 1947) nakazało UB wzmocnić represje wobec duchowieństwa i nakłaniać księży do nieczytania listu pasterskiego biskupów ${ }^{22}$. W decyzjach powziętych przez biuro polityczne duchowieństwo katolickie uznano za niebezpiecznego wroga ideologicznego i poddano polityce terroru ${ }^{23}$. Należy zaznaczyć, że podejmowane przez władze działania w pierw-

${ }^{18}$ Orędzie Episkopatu do wiernych $w$ sprawie matżeństwa, „Kronika Diecezji Włocławskiej” (dalej KDW), 40 (1946) s. 2-7.

${ }^{19}$ B. Cywiński, Ogniem próbowane. ... i was prześladować będa”, t. 2, Lublin 1990, s. 34. Unieważnienie konkordatu odbierało Kościołowi możliwość obrony swych praw przez odwołanie się do umowy międzynarodowej, a władzom PRL dawało wolną rękę w dekretowaniu sytuacji prawnej polskiego Kościoła. W dalszej jednak perspektywie dawało Kościołowi możliwość uzupełnień i zmian osobowych, bez konieczności uzyskiwania zgody władz państwowych.

${ }^{20}$ B. Fijałkowska, Partia wobec religii i Kościoła w PRL, t. 1: 1944-1955, Olsztyn 1999, s. 3850. Władze w Polsce nie przyjęły do oficjalnej wiadomości mianowania administratorów apostolskich dokonanego 16 VIII 1945 roku.

${ }^{21}$ W. Szafrański, Nauka religii w nowej Polsce, „Ateneum Kapłańskie” (dalej: AK), 45 (1946) s. $80-85$.

${ }^{22}$ Gryz, Władze partyjno-państwowe, s. 114. Ograniczeniu wpływów Kościoła poświęcono ogólnokrajową odprawę,,aktywu kierowniczego" w MBP (13-15 X 1947). Referat programowy pt. Ofensywa kleru a nasze zadania wygłosiła J. Brystygierowa. Efektem postanowień podjętych na tym spotkaniu była infiltracja duchowieństwa przez ok. 2 tys. funkcjonariuszy UB. Rozpracowywaniem duchowieństwa zajmował się też Główny Zarząd Informacji WP.

${ }^{23}$ „Biuletyn Informacyjny Ministerstwa Bezpieczeństwa Publicznego”, 1 (1947) nr 20, s. 210. 
szych latach powojennych stanowiły jedynie wstęp do podporządkowania Kościoła aparatowi państwa.

Również w ramach poszczególnych diecezji toczyły się spory z władzami. I tak w diecezji włocławskiej prowadzono spór między Włocławską Kurią Diecezjalną, a władzami miasta o zwrot budynku Niższego Seminarium Duchownego, cmentarza grzebalnego i ogrodu seminaryjnego ${ }^{24}$.W tym czasie trwał też konflikt wokół ksiąg stanu cywilnego, które dotychczas były prowadzone przez parafie ${ }^{25}$. Kategoryczny sprzeciw wobec zabierania parafialnych ksiąg metrykalnych wyraził proboszcz i dziekan nieszawski ks. Antoni Kiszkurno. Wierni stanęli po stronie proboszcza. Doszło do siłowej konfrontacji. Wobec agresywności władz parafianie nieszawscy, mając większość, pobili do nieprzytomności milicję, która chciała aresztować proboszcza. Księdza aresztowano jednak podstępem i skazano 3 VI 1946 roku na karę 3 lat więzienia; na wolność wyszedł w sierpniu 1946 roku, a resztę kary darowano ${ }^{26}$.

Należy zaznaczyć, że władze komunistyczne przez cały czas intensywnie prowadziły inwigilację duchowieństwa. I tak np. w diecezji włocławskiej po zakończeniu wojny organa bezpieczeństwa oskarżyły ks. Mariana Bruzdę, iż ten nocował i żywił członków podziemia antykomunistycznego, a ks. Serafina Opałko, że miał należeć do jednej z nielegalnych organizacji walczących z ludowym państwem polskim. Za wrogą działalność uznano też pobłogosławienie związku małżeńskiego żołnierza podziemia przez ks. Stanisława Boguckiego z Mąkoszyna w $1946 \mathrm{roku}^{27}$. Z kolei ks. Sylwestrowi Pawłowskiemu ze Zgromadzenia Misjonarzy Świętej Rodziny w Kazimierzu Biskupim zarzucano, że przechowywał w tamtejszym klasztorze uciekiniera $\mathrm{z}$ więzienia. $\mathrm{O}$ atakowanie w kazaniach partii i rządu oskarżano także proboszcza z Mazowsza, ks. Czesława Żurmanowicza ${ }^{28} . Z a$ wystąpienia antypaństwowe władze oskarżyły też w styczniu 1948 roku wikariusza parafii Wszystkich Świętych w Sieradzu, ks. Jan Szczesiaka' ${ }^{29}$. Z kolei w 1949

${ }^{24}$ K. Rulka, Biskupi i Kuria Diecezjalna w powojennym Włocławku, KDW, 82 (1999) s. 426427; J. Dębiński, Biskup włocławski Karol Mieczysław Radoński (1883-1951). Życie i działalność, Toruń 2001, s. 271. Na znak protestu przeciwko bezprawnemu działaniu władz ks. Władysław Szafrański 10 X 1945 roku złożył mandat radnego Miejskiej Rady Narodowej we Włocławku.

${ }^{25} \mathrm{~K}$. Grzesiak, Relacje państwo-Kościót katolicki na terenie diecezji włocławskiej $w$ latach 1945-1989, Toruń 2009, s. 143. W diecezji włocławskiej najbardziej przeciwko urzędom stanu cywilnego protestowało duchowieństwo powiatów włocławskiego, lipnowskiego i nieszawskiego.

${ }^{26}$ W. Rozynkowski, Kronika parafii nieszawskiej z lat 1945-146. Źródło do dziejów stosunków państwo-Kościót w okresie powojennym, „Zapiski Kujawsko-Dobrzyńskie”, 14 (2000) s. 271; R. Małecki, Śp. ks. kan. Antoni Kiszkurno, KDW, 87 (2004) s. 408-409; A. Poniński, Kiszkurno Antoni (1911-2004), kapłan diecezji włocławskiej, w: Leksykon duchowieństwa represjonowanego w PRL, t. 3, s. 90-93. Ks. Kiszkurno zarzucano też, że w kazaniach krytykowal projekt reformy prawa małżeńskiego.

${ }^{27}$ A. Kopiczko, Bogucki Stanistaw (1907-1996), kapłan diecezji łuckiej, w: Leksykon duchowieństwa represjonowanego $w$ PRL, t. 1, s. 21-23.

${ }^{28}$ Dębiński, Biskup włocławski, s. 276.

${ }^{29}$ A. Poniński, J. Żurek, Szczesiak Jan (1915-1985), kapłan diecezji włocławskiej, w: Leksykon duchowieństwa represjonowanego w PRL, t. 3, s. 235-237; E. Stachura, Ks. Jan Szczesiak, KDW, 68 (1985) s. 273-274. Aresztowany i uwięziony 5 I 1948 roku pod zarzutem usiłowania zmiany ustroju 
roku za rzekomą współpracę z Niemcami skazano na 8 lat więzienia byłego proboszcza parafii Charłupia Wielka, ks. Antoniego Samulskiego (po zakończeniu II wojny światowej pracował na terenach Dolnego Śląska ${ }^{30}$. W tym samym roku funkcjonariusze Wojewódzkiego Urzędu Bezpieczeństwa Publicznego w Sieradzu aresztowali proboszcza parafii Wągłczew, ks. Wacława Oponowicza ${ }^{31}$. Usunięto też ze stanowiska włocławskiego katechetę, ks. Bolesława Perzynę; ukrywał się do $1956 \mathrm{roku}^{32}$. W ramach tzw. akcji ,K”, skierowanej przeciwko inteligencji, duchowieństwu i chłopom przeciwstawiającym się kolektywizacji, aresztowano dwóch proboszczów ks. Apolinarego Leśniewskiego z Sieradza i ks. Franciszka Bieruta z Wilczyna. Ten pierwszy został skazany na 5 lat więzienia za to, że nie podpisał tzw. Apelu Sztokholmskiego i nie doniósł władzom o powstaniu w 1948 roku nielegalnego Związku Młodzieży Patriotycznej (zmienioną później na „,Ka$\left.t y n^{\prime \prime}\right)^{33}$. W przypadku natomiast ks. F. Bieruta oskarżono go, iż wypowiadał się w 1948 roku w Kazimierzu Biskupim przeciwko oddawaniu świadczeń przez rolników. Ponadto dołączono jeszcze jego wypowiedzi, jako już proboszcza parafii Wilczyn. W procesie karnym wymierzono ks. Bierutowi wyrok dwóch lat wiezienia; wyszedł $\mathrm{z}$ więzienia w 1952 roku $^{34}$. Do konfrontacji pomiędzy biskupem włocławskim Karolem Radońskim, a I sekretarzem KM PPR we Włocławku Remigiuszem Waberskim doszło na początku 1948 roku. Ordynariusz włocławski zwrócił się z apelem do wojska i milicji o udział w uroczystościach Bożego Ciała. W odpowiedzi I sekretarz PPR zakazał członkom partii uczestniczenia w tym święcie oraz polecił zorganizowanie konkurencyjnych zabaw ludowych dla wojska i młodzieży, które miały przynajmniej część ludzi odciągnąć od tradycyjnej procesji. Jak wynika ze sprawozdania KM PPR we Włocławku za maj 1948 roku większość członków poczuła się obrażona na sekretarza i wbrew jego zakazowi wzięła udział w procesji, za co biskup K. Radoński podziękował im w specjalnym liście pasterskim skierowanym do mieszkańców Włocławka ${ }^{35}$.

Władze komunistyczne przy różnych okazjach zarzucały duchowieństwu katolickiemu wręcz kliniczną wrogość wobec komunizmu i powojennej rzeczywi-

przemocą. Po raz drugi aresztowany 22 IV 1959 roku za próbę odzyskania parafialnej ziemi zabranej parafii Krzywosądz i po raz trzeci aresztowany w parafii Szadek 12 VIII 1968 roku za egzekwowanie wymogów wynikających z prawa kanonicznego.

${ }^{30}$ A. Poniński, Samulski Antoni (1897-1952), kapłan diecezji włocławskiej, w: Leksykon duchowieństwa represjonowanego $w$ PRL, t. 3, s. 194-195.

${ }^{31}$ Tenże, Oponowicz Wacław (1904-1974), kapłan diecezji włocławskiej, w: Leksykon duchowieństwa represjonowanego $w$ PRL, t. 3, s. 152-153; E. Stachura, Ks. Wacław Oponowicz, KDW, 58 (1975) s. 212. Do diecezji włocławskiej przybył w 1946 roku z archidiecezji lwowskiej i został proboszczem parafii Wągłczew, k. Sieradza. Aresztowany przez UB w Łodzi 2 VIII 1949 roku i skazany 7 I 1950 roku na karę 15 lat wiezienia za współpracę z grupami dywersyjnymi „Murata” i „Kuby” oraz wydawanie „fałszywych”; zwolniony 26 IV 1955 roku.

${ }^{32}$ Poniński, Represje wobec duchowieństwa, s. 353.

${ }^{33}$ A. Poniński, Leśniewski Apolinary (1891-1984), kapłan diecezji włocławskiej, w: Leksykon duchowieństwa represjonowanego w PRL, t. 1, s. 147-148; Dominiczak, Organy bezpieczeństwa s. 316.

${ }^{34}$ Poniński, Represje wobec duchowieństwa, s. 354-362.

${ }^{35}$ Dębiński, Biskup włocławski, s. 266. 
stości. Nie mając racji merytorycznych oskarżały Kościół o wykorzystywanie w tej walce ambony i konfesjonału oraz wspieranie podziemia antykomunistycznego. Tak było w przypadku ks. Mariana Łososia, proboszcza parafii Szynkielów w diecezji częstochowskiej ${ }^{36}$. Oskarżono go o pomoc udzielaną konspiracyjnemu Wojsku Polskiemu, a w konsekwencji o udział w działalności terrorystyczno- rabunkowej i skazano 29 IV 1949 roku na karę śmierci, którą zamieniono na dożywotnie więzienie; był więźniem obozu koncentracyjnego w Dachau. Karę odbywał we Wronkach do $1956 \mathrm{roku}^{37}$. W tym czasie aresztowano też znanego działacza społeczno-politycznego i publicystę ks. Zygmunta Kaczyńskiego, którego skazano w 1951 roku na 10 lat wiezienia; zmarł w wiezieniu $13 \mathrm{~V} 1953 \mathrm{roku}^{38}$. Z kolei zarzut o udział w Harcerskiej Organizacji Podziemnej i usiłowanie zmiany ustroju państwa polskiego przemocą, postawiono w 1950 roku ks. Józefowi Śmietanie; otrzymał karę dożywotniego wiezienia, za wychowywanie młodzieży w duchu wrogim do obecnego ustroju, zwłaszcza postępowej organizacji młodzieżowej $\mathrm{ZMP}^{39}$. Z oskarżenia o usiłowanie dokonania zmiany ustroju siłą skazany został na karę 12 lat więzienia jezuita o. Tomasz Roztworowski ${ }^{40}$.

Nasilenie antyklerykalnej polityki komunistycznych władz przeciwko Kościołowi zbiegło się z objęciem prymasostwa przez abp. Stefana Wyszyńskiego, zjazdem zjednoczeniowym PZPR i przejęciem przywództwa partyjnego przez Bolesława Bieruta ${ }^{41}$. Sformułowane w okresie rządów Bieruta cele polityki wyznaniowej można sprowadzić do trzech: dezintegracji, marginalizacji, wasalizacji. Władze wciąż zarzucały Kościołowi, że niektórzy księża popierają działalność komunistycznego podziemia. Nieustannie atakowano biskupów Czesława Kaczmarka z Kielc i Stanisława Adamskiego z Katowic ${ }^{42}$.

Okresem szczególnej represji wobec Kościoła były lata 1948-1955, kiedy to miały miejsce m.in. usuwanie biskupów z diecezji, aresztowania, procesy ${ }^{43}$. Zmasowany atak na Kościół przypuszczono po liście papieża Piusa XII do biskupów

${ }^{36}$ J. Związek, Łosoś Marian (1910-1978), kapłan diecezji częstochowskiej, w: Leksykon duchowieństwa represjonowanego $w$ PRL, t. 1, s. 158-160.

${ }^{37}$ A. Witkowski, Polityka karna organów wymiaru sprawiedliwości narzędziem represji wobec osób duchownych i konsekrowanych, w: Represje wobec osób duchownych, s. 142. Ks. M. Łosoś po wyjściu z więzienia we Wronkach twierdził, że jego pobyt w obozie koncentracyjnym w Dachau to były wczasy.

${ }^{38}$ J. Żaryn, Kaczyński Zygmunt (1894-1953), kapłan archidiecezji warszawskiej, w: Leksykon duchowieństwa represjonowanego w PRL, t. 1, s. 104-106.

${ }^{39}$ T. Balbus, K. Szwagrzyk, Śmietana Józef (1910-1975), kapłan archidiecezji wrocławskiej, w: Leksykon duchowieństwa represjonowanego w PRL, t. 1, s. 283-285; Bombicki, Księża, s. 162.

${ }^{40}$ W. Obirek, Roztworowski Tomasz (1904-1974), jezuita, w: Leksykon duchowieństwa represjonowanego w PRL, t. 1, s. 245-246; M. R. Bombicki, Księża, s. 215.

${ }^{41}$ A. Micewski, Kardynat Wyszyński. Prymas i mąż stanu, Paryż 1982, s. 61-62.

${ }^{42}$ H. Misztal, Divide et impera. Niszczenie struktur kościelnych i represje wobec duchownych $w$ Polsce jako jedna z metod walki systemu stalinowskiego $w$ Polsce, w: Represje wobec osób duchownych, s. 30-31.

${ }^{43}$ A. Dudek, Polityka władz Polski Ludowej wobec Kościoła Katolickiego - trwanie i zmiana, w: Represje wobec osób duchownych, s. 16. W 1953 roku PZPR postanowiło wobec Kościoła stosować politykę represji wobec reakcyjnej grupy duchowieństwa, pozyskać część kleru wobec lojalne- 
niemieckich z 1 III 1948 roku, w którym podkreślał on ogrom tragedii wysiedlonych i wspominał o możliwości rewizji powojennych układów pokojowych. Na kanwie zmasowanej akcji przeciwko Kościołowi organizowano masówki potępiające papieża i wspierający go „reakcyjny kler”, zlikwidowano część szkół katolickich, usunięto niewygodnych katechetów oraz odebrano niektórym biskupom paszporty ${ }^{44}$. Kierując się przewrotnością polityczną opublikowano 5 VIII 1949 roku dekret prezydenta B. Bieruta „O ochronie wolności sumienia i wyznania”, który zobowiązywał wszystkie organizacje katolickie do rejestracji i przedłożenia list członków oraz programu działania. Na taką postawę władz biskupi zareagowali rozwiązaniem wszystkich organizacji katolickich ${ }^{45}$.

Szczególny atak na Kościół nastąpił po oświadczeniu (18 III 1949) ministra Administracji Publicznej Władysława Wolskiego złożonym na ręce sekretarza Episkopatu bp. Zygmunta Choromańskiego o antypaństwowej postawie pewnych odłamów kleru. Oświadczenie opublikowano w środkach masowego przekazu. Przy tej okazji zaktywizywono przeciwko Kościołowi młodzież ZMP, działaczki Ligi Kobiet, a nawet Samopomoc Chłopską. Całej akcji służył rozbudowany aparat cenzorski. Tematykę religijną zaczęto rugować z życia publicznego, a księży przedstawiać jako postacie negatywne ${ }^{46}$. Agresja przeciwko Kościołowi nasiliła się po ogłoszeniu 1 VII 1949 roku dekretu Świętego Oficjum o ekskomunice dla tych, którzy będą współpracować z komunistyczną partią. Sytuację zaognił również tzw. cud lubelskit ${ }^{47}$. Wobec zdecydowanej postawy Kościoła władze postano-

go wobec siebie, wpływać na stopniowe uniezależnianie się Kościoła od Stolicy Apostolskiej oraz jak największa jego marginalizacja z życia społecznego; sprowadzenie do kruchty.

${ }^{44}$ Gryz, Władze partyjno-państwowe, s. 115; P. Raina, Kościót w PRL. Kościót katolicki a państwo w świetle dokumentów 1945-1989, t. 1: Lata 1945-1959, Poznań 1994, s. 163-166; J. Dębiński, Komunistyczne władze PRL wobec Kościoła rzymskokatolickiego w diecezji włocławskiej w latach 1945-1990, w: Rok 1945 na Kujawach i Pomorzu. Koniec wojny - poczatek nowej rzeczywistości, red. Z. Biegański i Z. Karpus, Bydgoszcz 2006, s. 227. W dyrektywie Biura Politycznego PPR do komitetów wojewódzkich pisano, że ,pierwszym zadaniem jest uzmysłowienie całemu społeczeństwu antypolskiej pozycji papieża i poderwanie zaufania w społeczeństwie do reakcyjnej postawy politycznej Episkopatu. Drugim zadaniem, jakie trzeba osiągnąć, to pogłębienie fermentu wewnątrz obozu katolickiego".

${ }^{45}$ M. Pietrzak, Prawo wyznaniowe, Warszawa 1993, s. 165; Grześkowiak, Prawo karne, s. 81. Ostrze przepisów skierowane było przeciwko duchowieństwu. O karze pozbawienia wolności w przypadku zmuszania kogoś do spowiedzi, uczęszczania do kościoła stwierdzał art. 3 dekretu z 5 VIII 1949 roku. Również karze mieli podlegać, zgodnie z art.4 wspomnianego dekretu, księża, którzy odmówiliby komukolwiek z powodów politycznych udzielenia ślubu, chrztu czy udziału w pogrzebie.

${ }^{46}$ Micewski, Kardynat Wyszyński, s. 63.

${ }^{47}$ J. Ziółek, A. Przytuła, Represje wobec uczestników wydarzeń w Katedrze Lubelskiej w 1949 roku, Lublin 1999. Wiadomość o pojawieniu się 3 VII 1949 roku łez na obrazie Matki Bożej w katedrze w Lublinie szybko rozprzestrzeniła się wśród wiernych. Następnego dnia przed katedrą zbierali się ludzie, którzy oczekiwali na obejrzenie obrazu. Urząd Bezpieczeństwa w Lublinie rozpoczął ograniczenie możliwości dotarcia do lubelskiej katedry. Lubelski biskup Piotr Kałwa wydał nawet oświadczenie dotyczące wydarzenia, w którym stwierdził, że to zjawisko nie może zostać uznane za cudowne i poprosił o zaprzestanie pielgrzymek. Do Lublina jednak przyjeżdżało coraz więcej osób, 
wiły dokonać zmasowanego uderzenia, tworząc z inicjatywy Hilarego Minca (22 VII 1949) nowy „plan akcji antyklerykalnej”48. Dekretem z 23 XI 1949 roku zakazano zbiorowych pielgrzymek, procesji na drogach publicznych, święcenia pól i wznoszenia krzyży i figur przydrożnych ${ }^{49}$.

W związku z likwidacją „Caritasu” zatrzymano i uwięziono pod zarzutem niegospodarności lub przestępstw obyczajowych i kryminalnych znaczną grupę duchownych i osób świeckich ${ }^{50}$. Odpowiedzią na przejęcie przez władze państwowe kontroli nad kościelną instytucją „Caritas” było podjęcie przez Konferencję Episkopatu Polski 30 I 1950 roku uchwały o likwidacji tej katolickiej instytucji dobroczynnej. Odtąd praca charytatywna prowadzona była pod hasłem „Miłosierdzia Chrześcijańskiego" tylko w ramach duszpasterstwa parafialnego ${ }^{51}$. Episkopat wystosował również (30 I 1950) list protestacyjny do prezydenta Bolesława Bieruta w sprawie likwidacji „Caritasu”,52.

Chcąc zaradzić konfliktowej sytuacji w relacjach państwo Kościół powołano, z inicjatywy prymasa S. Wyszyńskiego, Komisję Mieszana, która miała na celu rozwiązywać sprawy konfliktowe; swoje prace rozpoczęła od lipca 1949 roku $^{53}$. W rzeczywistości, mimo podpisanego 14 IV 1950 roku porozumienia, władze PRL od początku nie dotrzymywały zobowiązań ${ }^{54}$. Stąd nie zważając na jej działalność prowadziły represyjną politykę wobec Kościoła, czego przykładem są wy-

co budziło wściekłość służby bezpieczeństwa. W dniu 16 VI samochód służby bezpieczeństwa wjechał w uczestników procesji, którzy następnie go wywrócili i zaatakowali milicjantów. W dniach 10-17 VII doszło do licznych aresztowań, które objęły także księży pracujących w katedrze, czego skutkiem było jej zamknięcie.

${ }^{48}$ J. Poksiński, Przeciw Kościołowi, „Karta”, 9 (1992) s. 138.

${ }^{49}$ Kumor, Historia Kościoła, t. 8, s. 480.

${ }^{50}$ J. Myszor, Portret zbiorowy duchowieństwa represjonowanego w PRL (1944/1945-1989) w: Represje wobec duchowieństwa, s. 102; D. Zamiatała, Caritas. Działalność i likwidacja organizacji 1945-1950, Lublin 2000, s. 306. Do siedemnastu związków diecezjalnych oraz Krajowej Centrali „Caritas” i jej przedstawicielstw w Warszawie i w Gdyni wkroczyły grupy likwidacyjne. Dokonały opieczętowania biur i magazynów, zablokowały wszystkie konta bankowe związków i oddziałów parafialnych bez jakichkolwiek formalności administracyjnych.

${ }^{51}$ Zamiatała, Caritas, s. 319.

${ }^{52}$ Raina, Kościół w PRL, s. 207-210; K. Grzesiak, Państwo a Kościót katolicki w diecezji włoctawskiej w aspekcie stosunków własnościowych w PRL. Sprawa Zwiąku ,Caritas”, AK, 144 (2005) s. 48. Przez likwidację „Caritasu” wstrzymana została zagraniczna pomoc dla Polski, której dystrybuowaniem zajmował się kościelny „Caritas”. Uderzyło to w liczne rodziny, które korzystały z tego typu wsparcia.

${ }^{53}$ Gryz, Władze partyjno-państwowe, s. 120. Stronę rządową reprezentował minister Wolski, członek Biura Politycznego KC PZPR Franciszek Mazur oraz wiceminister obrony narodowej Edward Ochab. Kościół reprezentowali biskupi Choromański (sekretarz Episkopatu), Klepacz i Zakrzewski.

${ }^{54}$ Misztal, Divide et impera, s. 33; Raina, Kościół w PRL, s. 231-235. Tzw. porozumienie nakładało na Kościół obowiązek nauczania wiernych w duchu szacunku dla władzy państwowej i karania kanonicznego duchownych za działalność podziemną. Z kolei Episkopat miał zwrócić się do Stolicy Apostolskiej o utworzenie ordynariatów dla tzw. Ziem Zachodnich i Północnych. Kościół miał prawo prowadzić działalność dobroczynną, a także duszpasterską w szpitalach, wojsku i zakładach karnych oraz możliwość organizowania pielgrzymek. 
roki śmierci wykonane na ks. Rudolfie Marszałku (10 III 1948) ${ }^{55}$ i ks. Władysławie Gurgaczu (14 IX 1949), jezuicie z Krynicy, kapelanie Polskiej Podziemnej Armii Niepodległościowej ${ }^{56}$.

W myśl sugestii J. Stalina wypowiedzianej 1 VIII 1949 roku do B. Bieruta w Moskwie, że „przy klerze nie zrobicie nic, dopóki nie dokonacie rozłamu na dwie odrębne i przeciwstawne grupy"57, władze w Polsce podjęły dywersyjną działalność odśrodkową w Kościele, powołując 2 IX 1949 roku przy ZBoWiD tzw. ruch księży patriotów lub kleru postępowego, a rok później Komisję Księży Intelektualistów i Działaczy Katolickich przy Ogólnopolskim Komitecie Obrońców Pokoju związanych z „Dziś i Jutro” Bolesława Piaseckiego i Stowarzyszeniem PAX powstałym w 1947 roku $^{58}$. To „księżom patriotom” i stronnikom Bolesława Piaseckiego przekazano zrabowany majątek kościelnej organizacji charytatywnej, „Caritas” (23 I 1950) ${ }^{59}$. Za protesty w sprawie likwidacji „Caritasu” na dwa tygodnie aresztu domowego (w lutym 1950) skazano bp. chełmińskiego, Kazimierza Kowalskiego ${ }^{60}$.

Działania księży skupionych w Komisji z dnia na dzień radykalizowały się, czego przykładem jest napad tzw. księży patriotów na początku lutego 1953 roku na kurie biskupie, w Opolu, Płocku i we Włocławku oraz akceptacja aresztowania prymasa S. Wyszyńskiego ${ }^{61}$. I chociaż ruch ten od 12 VII 1955 roku przestał istnieć, to jednak został reaktywowany w 1959 roku w ramach Kół Księży przy

${ }^{55}$ Żurek, W obliczu śmierci, s. 268.

${ }^{56} \mathrm{~J}$. Szarek, Osaczony kapelan. Agentura wokót ks. Władysława Gurgacza, w: Kościót w godzinie próby 1945-1989. Nieznane dokumenty i świadectwa, Kraków 2003, s. 28-39.

${ }^{57}$ Dudek, Państwo i Kościót, s. 17.

${ }^{58}$ Gryz, Władze partyjno państwowe, s. 108; B. Bankowicz, Ruch księży patriotów 1949-1955, czyli „koń trojański” w polskim Kościele katolickim, w: B. Bankowicz, A. Dudek, Ze studiów nad dziejami Kościoła i katolicyzmu w PRL, Kraków 1996, s. 11. Głównym zadaniem „księży patriotów”, określanych często przez samych siebie „szarą bracią kapłańską” było uniezależnienie polskiego kościoła katolickiego od Rzymu i podporządkowanie władzom komunistycznym w Polsce. Cele te starano się osiągnąć poprzez przekazywanie informacji związanych z funkcjonowaniem Kościoła, wpływanie na obsadę stanowisk kościelnych, przekazywanie materiałów ośmieszających pewnych duchownych, atakowanie słowne „niewygodnych” dla państwa duchownych. Liczba „księży patriotów” jest trudna do ustalenia; prawdopodobnie stanowili ok. 6-8\% duchowieństwa katolickiego. W 1953 roku połączono ZBOWiD-wską Komisję Księży z PAX-owskim Komitetem Intelektualistów i Działaczy Katolickich, tworząc Komisję Duchownych i Świeckich Działaczy Katolickich przy Ogólnopolskim Komitecie Frontu Narodowego.

${ }^{59}$ Dominiczak, Organy bezpieczeństwa, s. 123; J. Żaryn, , Księża patrioci”-geneza powstania formacji duchownych katolickich, Polska 1944/45-1989. Studia i materiaty, t. 1, Warszawa 1995, s. 13; Żaryn, Kościół a władza, s. 317-321; Gryz, Władze partyjno-państwowe, s. 122. Państwo przejęło tzw. dobra „martwej ręki”, tj. ok. 80 \% ziemi należącej do Kościoła (ok. 155 tys. ha) i utworzyło tzw. Fundusz Kościelny, z którego finansowano prześladowanie Kościoła oraz ruch „księży patriotów".

${ }^{60}$ Gryz, Władze partyjno-państwowe, s, 121

${ }^{61}$ W.J. Wysocki, J. Żurek, Wyszyński Stefan (1901-19810, Prymas Polski, w: Leksykon duchowieństwa represjonowanego w PRL, t. 1, s. 313-317; W. Szafrański, Ks. Adam Śniechowski, KDW, 54 (1971) s. 193-194. 
Zrzeszeniu Katolików Caritas. Mimo, że w 1961 roku Episkopat Polski w specjalnym piśmie zabronił duchownym uczestniczenia w tych strukturach, przetrwał aż do $1990 \mathrm{roku}^{62}$.

W związku z aktywną działalnością księży patriotów w diecezji włocławskiej, bp K. Radoński wydał 30 X 1950 roku Przestroge pasterska i specjalny dekret (wszedł w życie 6 I 1951), w którym zakazał czytania i propagowania pism antyklerykalnych pod karą suspensy, jemu osobiście zarezerwowanej ${ }^{63}$.

Okresem intensywnej walki komunistów z Kościołem był rok 1951. Aresztowano wtedy (20 I 1951) pod zarzutami kolaboracji z okupantem niemieckim i szpiegostwa na rzecz USA biskupa kieleckiego Czesława Kaczmarka ${ }^{64}$. Od stycznia 1951 roku toczył się też proces przeciwko Konspiracyjnej Armii Polskiej. Na ławie oskarżonych zasiedli dwaj krakowscy księża Piotr Oborski i Zbigniew Gadomski ${ }^{65}$ i kapłan diecezji włocławskiej, wikariusz parafii Zagórów ks. Jan Reniec; oskarżono go o potępianie w kazaniach doktryny marksistowskiej i wykazywanie, iż polscy żołnierze nie o taką Polskę walczyli ${ }^{66}$.

Chcąc całkowicie podporządkować sobie Kościół władze usunęły 26 I 1951 roku administratorów apostolskich pięciu diecezji na Ziemiach Odzyskanych (Gdańsk, Gorzów, Olsztyn, Opole, Wrocław), których zastąpili wskazanymi przez siebie wikariuszami kapitulnymi ${ }^{67}$. Prymas Polski S. Wyszyński, aby uniknąć po-

${ }^{62}$ J. Dębiński, Zmiany organizacyjne Kościoła rzymskokatolickiego w Polsce po 1945 r., „Grot - Zeszyty Historyczne poświęcone historii wojska i walk o niepodległość”, 28 (2007) s. 45.

${ }^{63}$ Archiwum Diecezji Włocławskiej, Akta personalne biskupa Karola Radońskiego, sygn. 280e, s. 159. Pasterska przestroga z 30 XII 1950; tamże, Dekret biskupa włocławskiego z 30 XII 1950, s. 160

${ }^{64}$ R. Gryz, Państwo a Kościót w Polsce 1945-1956 na przyktadzie województwa kieleckiego, Kraków 199, s. 257-261; R. Gryz, Sprawa biskupa Czesława Kaczmarka przykładem antykościelnej polityki w systemie stalinowskim, w: Państwo - Kościót - Europa nowe wyzwania, red. M. Drzonek, J. Mieczkowski i K. Kowalczyk, Szczecin 1999, s. 45-52; Witkowski. Polityka karna, s. 147-150. W oświadczeniu rządowym podano do wiadomości, że biskup miał „służalczy stosunek do okupanta hitlerowskiego".

${ }^{65}$ R. Gryz, Oborski Piotr (1907-1952), ksiądz diecezji kieleckiej, w: Leksykon duchowieństwa represjonowanego w PRL, t. 1, s. 205-206; R. Gryz, Gadomski Zbigniew (1921-1993), kaplan diecezji kieleckiej, w: Leksykon duchowieństwa represjonowanego w PRL, t. 1, s. 58-59; Informator o nielegalnych antypaństwowych organizacjach i bandach zbrojnych działajacych $w$ Polsce Ludowej w latach 1944-1956, Lublin 1993, s. 26. Po aresztowaniu w 1950 roku i dziewięciomiesięcznym śledztwie członków armii podziemnej w tym księży Piotra Oborskiego i Zbigniewa Gadomskiego w tzw. ,procesie wolbromskim" zapadł wyrok skazujący 3 osoby na karę śmierci, 5 spośród oskarżonych na dożywocie, a 46 otrzymało kary pozbawienia wolności do lat 15 . Ksiądz Oborski był jednym z tych, którzy otrzymali karę dożywotniego więzienia. Zmarł w szpitalu więziennym w Rawiczu 18 VI 1952 roku, będąc właściwie do końca torturowany. Sam proces był jednym z najgłośniejszych w czasach stalinowskich.

${ }^{66}$ A. Poniński, Reniec Jan (1910-1974), kapłan diecezji włocławskiej, w: Leksykon duchowieństwa represjonowanego w PRL, t. 1, s. 243-244; Dominiczak, Organy bezpieczeństwa, s. 93. Ks. Reniec został aresztowany 3 XII 1951 roku przez funkcjonariuszy UB z Konina i Poznania i skazany 26 IV 1952 roku przez sąd wojewódzki w Poznaniu na 3 lata więzienia, które opuścił w maju 1953 roku.

${ }^{67}$ Kumor, Historia Kościoła, t. 8, s. 481. 
padnięcia w schizmę, mianował wskazanych przez władze wikariuszy kapitulnych, wikariuszami generalnymi ${ }^{68}$. Dla poparcia swojej polityki władze zorganizowały też w połowie grudnia 1951 roku zjazd duchowieństwa we Wrocławiu pod hasłem polskości Ziem Zachodnich; oprócz „księży patriotów” zwieziono pod przymusem także innych księży (razem ok. 1,5 tys.) ${ }^{69}$.

W 1952 roku za wzywanie wiernych do protestów przeciwko usuwaniu religii ze szkół władze dekretem Komisji Specjalnej do Walki z Nadużyciami i Szkodnictwem Gospodarczym wydaliły 7 XI 1952 roku na pięć lat z terytorium diecezji biskupów katowickich ordynariusza Stanisława Adamskiego, jego koadiutora Herberta Bednorza oraz sufragana, Juliusza Bieńka ${ }^{70}$. W tym okresie na niespotykaną skalę władze ingerowały w politykę personalną poszczególnych biskupów. W końcu 1952 roku zmuszono niektórych biskupów do przeniesienia na inne placówki kościelne ponad 400 tzw. „,wrogich księży”. W tym samym roku rozwiązano 46 niższych seminariów duchownych ${ }^{71}$.W takiej krytycznej sytuacji biskupi prosili duchowieństwo, aby unikało jakichkolwiek wystąpień przeciwko władzom. Zachęcano do przetrwania trudnego okresu. Włocławskie Wiadomości Duszpasterskie uznały nawet za konieczne zamieszczenie wskazówek dla duchowieństwa na wypadek dalszego pogorszenia warunków pracy duszpasterskiej ${ }^{72}$.W tym też czasie w diecezji włocławskiej aresztowano i osadzono dwóch księży Tadeusza Czubaka ${ }^{73}$ i Zenona Krupińskiego ${ }^{74}$.Tego pierwszego oskarżono o współpracę z podziemiem, zwłaszcza grupą „Huragan” oraz o zamiar ucieczki za granicę; skazany, wyszedł na wolność warunkowo w październiku 1956 roku. Drugi z kolei, jako proboszcz parafii Zbiersk, oskarżony także o próbę nielegalnego opuszczenia kraju, został skazany na 10 lat wiezienia; wyszedł na wolność w 1956 $\mathrm{roku}^{75}$.

${ }^{68}$ Tamże, s, 481; Gryz, Władze partyjno-państwowe, s. 124. Władze w Polsce dążyły do mianowania ordynariuszy na terenach Ziem Odzyskanych. W tej nawet sprawie prymas S. Wyszyński udał się do Rzymu (4 IV - 1 V 1951).

${ }^{69}$ A. Micewski, Wspótrządzić czy nie kłamać? PAX i ZNAK w Polsce 1945-1976, Paryż 1978, s. 49.

${ }^{70}$ Gryz, Władze partyjno-państwowe, s, 126; Misztal, Divide et impera, s. 36. Wikariuszem kapitulnym został ksiądz „patriota” Juliusz Bednorz, brat sufragana katowickiego.

${ }^{71}$ H. Konopka, Religia w szkołach Polski Ludowej. Sprawa nauczania religii w polityce państwa (1944-1961), Białystok 1997, s. 136; Dominiczak, Organa bezpieczeństwa, s. 65.

${ }^{72}$ Dębiński, Komunistyczne władze PRL, s. 227.

${ }^{73}$ A. Poniński, Czubak Tadeusz (1909-1975), kapłan diecezji włocławskiej, w: Leksykon duchowieństwa represjonowanego w PRL, t. 3, s. 30-33; E. Stachura, Ks. Tadeusz Czubak, KDW, 58 (1975) s. 286; J. Sanak, „, Gorszy niż bandyta”. Kapłan w stalinowskim więzieniu, Kraków 2001, s. $69-71$.

${ }^{74}$ K. Banaś, Krupiński Zenon (1908-1983), kapłan diecezji włocławskiej, w: Leksykon duchowieństwa represjonowanego $w$ PRL, t. 2, s. 141-144; Informator o osobach skazanych za szpiegostwo w latach 1944-1984, Lublin 1994, s. 77. Będąc proboszczem parafii Zbiersk został zatrzymany przez UB 6 I 1952 roku za działalność antypaństwową. Sąd skazał go 18 II 1953 roku na 10 kat więzienia. Wyrok w kolejnym procesie zmniejszono do 6 lat. Warunkowo wyszedł na wolność w 1956 roku.

${ }^{75}$ Poniński, Represje wobec duchowieństwa, s. 367-369. 
W 1953 roku z oskarżenia o szpiegostwo odbył się pokazowy proces księży i świeckich pracowników kurii krakowskiej. Zapadły trzy wyroki, w tym kara śmierci dla ks. Józefa Lelito, ${ }^{76} 15$ lat więzienia dla ks. Wita Brzyckiego; warunkowo opuścił wiezienie w 1954 roku $^{77}$ i 13 lat wiezienia dla ks. Józefa Fudali; zmarł w więziennym szpitalu w 1955 roku $^{78}$. Internowano również abp krakowskiego Eugeniusza Baziaka ${ }^{79}$. Rada Państwa 9 lutego 1953 roku ogłosiła dekret (Dz.U. $\mathrm{Nr}$ 10. poz. 42) dotyczący zgody władz przy obsadzaniu stanowisk duchownych. W odpowiedzi na ten dekret Episkopat Polski skierował 8 maja 1953 roku specjalny memoriał, który przeszedł do historii pod nazwą „Non possumus" ${ }^{80}$. Apogeum prześladowań stanowił wyrok na biskupa kieleckiego Czesława Kaczmarka wydany 22 IX 1953 roku; skazano go na 12 lat więzienia, a sądzonych z nim księży na kary do 10 lat ${ }^{81}$. Przeciwko nadużyciom procesowym i nagonce prasowej zaprotestował stanowczo prymas S. Wyszyński, którego władze aresztowały 25 IX 1953 roku, a wraz z nim biskupów Antoniego Baraniaka z Poznania i Lucjana Biernackiego, sufragana gnieźnieńskiego (w 1953 roku uwięzionych było 12 biskupów i kilkuset księży); funkcję przewodniczącego Episkopatu Polski, zgodnie $\mathrm{z}$ wolą władz, sprawował bp. Michał Klepacz ${ }^{82}$. Władze komunistyczne zmusiły ówczesny Episkopat nie tylko do zatwierdzenia narzuconego mu przewodniczącego Konferencji Episkopatu, ale również do potępienia działalności biskupa kieleckiego Kaczmarka, a także do złożenia (17 XII 1953) ślubowania na wierność PRL ${ }^{83}$.W tę zmasowaną akcję przeciwko Kościołowi włączono także księży patriotów, którzy podjęli (30 I 1953) tzw. otwarty bunt, żądając m.in. usunięcia z kurii księży o antypaństwowych poglądach ${ }^{84}$.

W okresie stalinowskim stosowano nagminnie wobec księży przymus fizyczny oraz szantaż. Różnymi sposobami próbowano rozbijać Kościół od wewnątrz ${ }^{85}$. Zorganizowanej akcji przeciwko Kościołowi służył też powołany w 1953 roku

${ }^{76}$ P. Mardyła, F. Musiał, Lelito Józef (1915-1978), kapłan archidiecezji krakowskiej, w: Leksykon duchowieństwa represjonowanego w PRL, t. 2, s. 161-164. Aresztowany 12 XI 1952 roku, został skazany na karę śmierci, zamienioną w 1953 roku na dożywocie; postępowanie umorzono 27 IV 1956 roku.

${ }^{77}$ Isakowicz-Zaleski, Księża, s. 34.

${ }^{78}$ Tamże, s. 35.

${ }^{79}$ J. Żurek, Baziak Eugeniusz (1890-1962), metropolita lwowski, metropolita-nominat krakowski, w: Leksykon duchowieństwa represjonowanego w PRL, t. 2, s. 8-14; Misztal, Divide et impera, s. 37; F. Musiał i M. Lasota, Kościót zraniony. Proces księdza Lelity i sprawa kurii krakowskiej, Kraków 2003.

${ }^{80}$ Raina, Kościót Kościót w PRL, s. 413-427.

${ }^{81}$ A. Kochański, Polska 1944-1991. Informator historyczny, t. 1, Warszawa 1996, s. 507.

${ }^{82}$ R. Gryz, Państwo a Kościót w Polsce, Kraków 1999, s. 254; J. Zaryń, Aparat bezpieczeństwa wobec Kościoła katolickiego w Polsce (1944-1980), w: Represje wobec osób duchownych, s.110. Wobec prymasa nie stosowano przemocy fizycznej. Zrezygnowano też z procesu pokazowego.

${ }^{83}$ Dudek, Gryz, Komuniści i Kościót, s. 91-93; R. Gryz, Władze partyjno-państwowe, s. 126.

${ }^{84}$ Gryz, Władze partyjno-państwowe, s. 126.

${ }^{85}$ P. Raina, Stefan Kardynat Wyszyński Prymas Polski, t. 2, Londyn 1986, s. 63-64. Politykę społeczno-gospodarczą oraz kościelną rządu popierał Bogdan Piasecki, który w 1947 w porozumieniu Władysławem Gomułką stworzył Stowarzyszenie PAX. Jego książkę pt. Zagadnienia istotne 
przez Biuro Polityczne KC PZPR Wydział Organizacji Masowych i jego odpowiedniki wojewódzkie, jakimi były Referaty Organizacji Masowych ${ }^{86}$. Miejscem szczególnych prześladowań Kościoła w 1954 roku były: Opolszczyzna oraz Dolny i Górny Śląsk. Z tych terenów 3 sierpnia 1954 roku wywieziono, bez wyroku sądowego, do obozów pracy ok. tysiąca zakonnic ${ }^{87}$. Władze w swojej furii niszczenia Kościoła ograniczyły też działalność Katolickiego Uniwersytetu Lubelskiego, a z wydziałów w Krakowie i w Warszawie utworzono Akademię Teologii Katolickiej ${ }^{88}$.

Represji komunistycznych władz doświadczyło w 1955 roku dwóch włocławskich kapłanów - proboszcz parafii Brześć Kujawski, ks. Michał Ślipek ${ }^{89}$, który za rzekome szkalowanie władzy ludowej został skazany na rok więzienia w zawieszeniu na trzy lata oraz kanclerz kurii i wikariusz generalny ks. Stanisław Piotrowski ${ }^{90}$.

W najtrudniejszym okresie stalinizmu (1948-1953) ze wszystkich diecezji usunięto, aresztowano lub osądzono w więzieniu 9 biskupów; bezwzględnie obchodzono się z biskupem gdańskim Karolem Marią Splettem ${ }^{91}$. W sumie do 1956 roku zabito w Polsce 37 księży diecezjalnych i 54 zakonnych. W tym czasie zmarło też lub zaginęło 260 księży diecezjalnych, a przez więzienia przeszło ok. 700 kapłanów. Ponadto internowano ok. 450, a 900 wygnano. Niektórych księży wielokrotnie aresztowano; rekordzistą był ks. Józef Wójcik, który od końca lat 50 . był

oraz tygodnik „Dziś i Jutro” zostały wpisane w 1955 roku przez papieża Piusa XII na indeks ksiąg zakazanych.

${ }^{86}$ R. Gryz, Władze partyjno-państwowe odpowiedzialne za politykę wobec Kościoła katolickiego w Polsce (1944/45-1956), „Czasy Nowożytne”, 3 (1997) s. 115-120.

${ }^{87}$ A. Grajewski, Podludzie PRL, „Gość Niedzielny”, 3 (2008) s. 42-43. 21. 10 zgromadzeń żeńskich, głównie elżbietanki, służebniczki i franciszkanki, 3 VIII 1954 roku pozbawiono wolności i własności. Siostry były na ogół autochtonkami, Ślązaczkami, z których zdecydowana większość deklarowała narodowość polską; wiele z nich przeżywało szykany w czasach nazistowskich. W sumie zlikwidowano 100 domów zakonnych i wywieziono 1061 sióstr zakonnych, które umieszczono w domach centralnej Polski i w Wielkopolsce. Jednym z miejsc internowania była Dębowa Łąka w diecezji toruńskiej. Wszystkie klasztory, w których internowano zakonnice były pilnowane, a siostry izolowane od mieszkańców.

${ }^{88}$ Kumor, Historia Kościoła, s. 483.

${ }^{89}$ J. Dębiński, Ślipek Michał, w: Włocławski Słownik Biograficzny, t. 4, Włocławek 2006, s. 158 .

${ }^{90}$ J. Bąk, Piotrowski Stanisław (1912-1998), kapłan diecezji włocławskiej, w: Leksykon duchowieństwa represjonowanego $w$ PRL, t. 2, s. 221-222; S. Piotrowski, Czerwone szlabany, Kalisz 1990, s. 21-23; Dominiczak, Organy bezpieczeństwa, s. 89. Aresztowany 26 XI 1955 roku za sporządzanie i kolportowanie wśród młodzieży akademickiej i duchowieństwa „wrogiej literatury”. Śledztwo umorzono na mocy amnestii z 26 XI 1956 roku.

${ }^{91}$ S. Bogdanowicz, Splett Karol Maria (1898-1964), biskup gdański, w: Leksykon duchowieństwa represjonowanego w PRL, t. 2, s. 268-271; T. Bolduan, Biskup Carl Maria Splett - od mitów ku prawdzie, „Studia Pelplińskie”, 20 (1989) s. 79-95. Po zakończeniu wojny bp Splett został oskarżony przez władze polskie o dopuszczenie się zbrodni na narodzie polskim i skazany na 8 lat więzienia, którą odbył w całości. Pogwałceniem prawa było jego internowanie do 1956 roku Po zwolnieniu natychmiast wyjechał do Düsseldorfu, gdzie zmarł w 1964 roku. 
aresztowany aż dziesięć razy. Miejscem odbywania kary przez księży był głównie Rawicz i Wronki. W sumie przez te dwa więzienia w latach 1945-1956 przeszło 189 księży $^{92}$. Z diecezji włocławskiej w okresie tych 11 lat zostało skazanych na kary więzienia 14 księży oraz 7 sióstr zakonnych ze zgromadzenia ,Wspólna Praca”; jeden z włocławskich kapłanów ukrywał się przez 7 lat ${ }^{93}$.

Osłabienie działań przeciw Kościołowi nastąpiło w 1956 roku. Na mocy amnestii prawie wszyscy księża opuścili wiezienia, na wolność wyszedł (26 X 1956) prymas S. Wyszyński ${ }^{94}$. Stosunki państwo - Kościół zostały oparte na nowym porozumieniu z 8 XII 1956 roku $^{95}$.

Po wydarzeniach październikowych w latach 1956-1970 ukształtował się tzw. gomułkowski model walki z Kościołem. Rzadko wtedy aresztowano księży, poza przypadkami nielegalnego budownictwa obiektów sakralnych. Niemniej jednak Służba Bezpieczeństwa 20 VII 1958 roku wtargnęła do klasztoru jasnogórskiego, aresztowała świeckich i duchownych pracowników Instytutu Prymasowskiego i skonfiskowała religijne publikacje. W tym samym roku wydano też zarządzenie o usunięciu krzyży z budynków szkolnych i odsunięciu zakonników od nauczania religii ${ }^{96}$. W 1959 roku w Kraśniku Fabrycznym doszło do zamieszek z powodu usunięcia kaplicy i krzyża z miejsca obiecanej budowy kościoła. Do podobnych starć z milicją doszło także 27-28 VI 1960 roku w Nowej Hucie. W tym samym roku w czasie wakacji podjęto walkę z wszelkimi formami duszpasterstwa oazowego. Dokuczliwe dla księży stały się także różnego rodzaju domiary podatkowe i kary pieniężne ${ }^{97}$. Nieustanną inwigilacją, karami administracyjnymi i nagrywaniem kazań nękany był w tym czasie ks. Marian Włodarczyk. Oskarżano go o nadużywanie ambony do wystąpień publicznych niemających związku z kultem religijnym, nie został również zatwierdzony na stanowisko proboszcza parafii Skęczniew $^{98}$.

W 1959 roku władze komunistyczne zdecydowały utworzyć organizację księżowską, będąca przeciwwagą dla Episkopatu. W efekcie powstało Centralne Koło

${ }^{92} \mathrm{~T}$. Kostewicz, Wykonane kary więzienia wobec osób duchownych i konsekrowanych $w$ latach 1944-1956, w: Represje wobec osób duchownych, s. 220-236; Myszor, Portret zbiorowy, s. 100.

${ }^{93}$ Poniński, Represje wobec duchowieństwa, s. 375-376.

${ }^{94}$ Myszor, Portret zbiorowy, s. 105.

${ }^{95}$ Kumor, Historia Kościoła, s. 487. Przywrócono katechezę jako przedmiot nadobowiązkowy oraz opiekę duszpasterską nad chorymi i więźniami. Wznowiono wydawanie prasy katolickiej i zezwolono na powstanie 6 Klubów Inteligencji Katolickiej, wycofano także dekret z 9 II 1953 roku, a w jego miejsce wprowadzono z 31 XII 1956 roku mniej restrykcyjny O organizowaniu i obsadzaniu stanowisk kościelnych.

${ }^{96}$ Dudek, Polityka władz, s. 17. W więzieniach przebywał kleryk Michał Żak, do 1958 roku i ks. Zbigniew Gadomski, do 1960 roku.

${ }^{97}$ List KC PZPR z lipca 1958 roku do egzekutyw Komitetów Wojewódzkich, Powiatowych i Miejskich PZPR, w: S. Markiewicz, Stosunki miedzy państwem a Kościotem rzymskokatolicki w Polsce Ludowej(1944-1981), cz. 2, Warszawa 1982, s. 20-34.

${ }^{98}$ K. Rulka, Ks. Marian Włodarczyk, KDW, 87 (2004) s. 561-562. Przez władze bezpieczeństwa uważany był za „wojownika” z komunizmem. Przeciwko niemu występowały władze urzędów wojewódzkich w Bydgoszczy (1963), Łodzi (1966), Poznania (1979) i Konina (1982). 
Księży Caritas. Znaczenie utworzonej grupy nie było już tak duże jak jej zbowidowskiej poprzedniczki.

Jednym z elementów walki z Kościołem była od 1959 roku służba wojskowa alumnów. O tym, który z alumnów miał służyć w wojsku decydował Zarząd Polityczny Wojska Polskiego w Warszawie. Celem tej akcji była dezorganizacja nauczania $\mathrm{w}$ seminarium ${ }^{99}$.

Z nowym rokiem szkolnym 1961/1962 usunięto nauczanie religii ze szkół wszystkich szczebli ${ }^{100}$. Zostało ono przeniesione do pozaszkolnych punktów katechetycznych ${ }^{101}$. Do walki z Kościołem utworzono w MSW w 1962 roku osobny Departament IV, którego struktura przetrwała aż do upadku komunizmu. Rok później (6 VII) MSW wydało instrukcję o objęciu kontrolą całego duchowieństwa i wszystkich placówek Kościoła oraz dokumentowania ich działalności w teczkach ewidencji operacyjnej (TEOK, TEOB i TEOP); takie materiały „na księdza” zaczęto gromadzić właściwie już od 1949 roku. Od 1963 roku każda z osób wstępujących do seminarium duchownego była natychmiast ewidencjonowana $\mathrm{w}$ tzw. TEOK - teczce ewidencji operacyjnej księdza ${ }^{102}$.

Minister Finansów 20 lutego 1962 roku wydał rozporządzenie w sprawie prowadzenia ksiąg przez kościelne osoby prawne i zakony, które w istotny sposób zmieniło obowiązujące przepisy. Począwszy od 1 maja 1962 roku kościelne osoby prawne i zakony zobowiązane zostały do prowadzenia ksiąg rachunkowej i inwentarza. Brak tych ksiąg a szczególnie księgi inwentarza stało się podstawą do wszczęcia licznych procesów sądowych, z których kilka zakończyło się przed

${ }^{99}$ W. Frątczak, Stużba wojskowa alumnów diecezji włocławskiej jako forma represji wobec Kościoła, AK, 144 (2005) s. 31. Od 1964 roku stworzono specjalne kleryckie jednostki (Bartoszyce, Szczecin - Podjuchy i Brzeg) wraz z dobraną kadrą i odpowiednim programem indoktrynacji.

${ }^{100}$ B. Fijałkowska, Partia wobec religii i Kościoła w PRL w okresie popaździernikowym, w: Społeczeństwo-Państwo - Kościót (1945-2000). Materiały z ogólnopolskiej konferencji naukowej, Szczecin, 15-16 VI 2000, red. A. Kawecki, K. Kowalczyk, A. Kubaj, Szczecin 2000, s. 28-33.

${ }^{101}$ Grzesiak, Relacje państwo-Kościót, s. 490-492. W roku szkolnym 1961/1962 w diecezji włocławskiej funkcjonowało 381 punktów katechetycznych. Katechizacją objęto $81 \%$ dzieci oraz 50-89\% młodzieży.

102 Żaryn, Aparat bezpieczeństwa, s. 112-113; Isakowicz-Zaleski, Księża, s. 21-22. Choć w latach 1989-1990 Departament IV MSW zniszczył większość TEOK, część z dokumentacji ocalała. Zakładano także teczki na kurie, seminaria, zgromadzenia zakonne, redakcje pism katolickich, stowarzyszenia. Szacunkowe dane świadczą, że liczba tajnych współpracowników wśród duchowieństwa katolickiego nie przekroczyła ok.10\%, a trzeba pamiętać, że było to środowisko najbardziej inwigilowane w czasach PRL i praktycznie każdy kapłan był obiektem zainteresowań werbowniczych. Ci, którzy współpracowali z bezpieką czynili to w różnych okolicznościach i każdy przypadek należy ukazywać indywidualnie, by nikogo nie krzywdzić. O wszelkich kontaktach z bezpieką oraz o składanych przez nią propozycjach współpracy należało informować biskupów. Stanowisko Episkopatu w tej sprawie (zapoczątkowane decyzją prymasa Wyszyńskiego) było niezmienne, więc ci spośród duchownych, którzy ukrywali swe kontakty przed biskupem ordynariuszem już przez sam fakt ukrywania ich byli nielojalni wobec Kościoła. 
Sądem Najwyższym. Decyzja ich prowadzenia wywołała protest Episkopatu skierowany 12 IV 1962 roku do Rady Ministrów ${ }^{103}$.

Zmasowana kampania propagandowa przeciwko Kościołowi rozpoczęła się przed uroczystościami związanymi z tysiącleciem chrztu Polski. Powodem był list biskupów polskich do biskupów niemieckich z formułą ,wybaczamy i prosimy o wybaczenie" (18 XI 1965). Chcąc dokuczyć Kościołowi komuniści organizowali konkurencyjne uroczystości, np. w Gnieźnie i Włocławku. W czasie przewożenia w maju i czerwcu z miasta do miasta kopii obrazu Matki Boskiej Częstochowskiej, milicja ,,aresztowała” obraz i przewiozła do Warszawy uniemożliwiając obrzędy peregrynacji ${ }^{104}$.

Lata tzw. okresu gierkowskego (1971-1980) upłynęły z kolei pod hasłem normalizacji stosunków z Kościołem. Zmiana jednak dotyczyła tylko formy, a nie treści. Wciąż istniały problemy z uzyskiwaniem zgody na budowę kościołów, zdobyciem materiałów budowlanych i przydziału papieru dla istniejących wydawnictw katolickich. Prasa katolicka była poddana silnej cenzurze ${ }^{105}$. W tym czasie funkcjonariusze SB doprowadzali do śmierci w 1976 roku ks. Romana Kotlarza $^{106}$.

Pomimo próby podjęcia przez władze komunistyczne na początku lat 70. XX w. pewnego wysiłku normalizacji stosunków dyplomatycznych ze Stolicą Apostolską ${ }^{107}$, dalej prowadzono cały szereg działań mających na celu antagonizowanie Episkopatu i Stolicy Apostolskiej ${ }^{108}$. Coraz większą aktywność w zwalczaniu duchowieństwa zaczął przejmować pion IV Służby Bezpieczeństwa. Minister spraw wewnętrznych Stanisław Kowalczyk powołał 19 XI 1973 roku w Departamencie IV tajną, przestępczą strukturę - samodzielną grupę „D”, która podlegała bezpośrednio dyrektorowi Departamentu IV, a jej zadaniem było „koordynowanie i organizowanie działań dezintegracyjnych wobec Kościoła”. Organizatorem tej

${ }^{103}$ Dudek, Państwo i Kościót, s. 158-159. Zniesienie obowiązku prowadzenia księgi inwentarzowej oraz przychodów i rozchodów zbiegło się w czasie z nawiązaniem przez rząd PRL rozmów ze Stolicą Apostolską.

${ }^{104}$ Tamże, s.181, 196; S. Wyszyński, Zapiski milenijne, Warszawa 2001, s. 191; Dębiński, Komunistyczne władze PRL, s. 238-239.

${ }^{105}$ Dudek, Polityka władz, s. 18.

${ }^{106}$ S. Kowalik, Kotlarz Roman (1928-1976), kapłan diecezji sandomierskiej, w: Leksykon duchowieństwa represjonowanego $w$ PRL, t. 1, s. 125-127. Jako proboszcz parafii Pelagowa, k. Radomia był dręczony przez UB. W 1976 roku brał udział w „wypadkach radomskich”. W kazaniach mówił o buncie robotników. Sprawę o morderstwo umorzono w 1991roku.

${ }^{107}$ Konkordat. Z bpem Alojzym Orszulikiem, zastępcą sekretarza generalnego Episkopatu Polski, rozmawia ks. Ireneusz Skubiś, w: Prawda o konkordacie, red. W. Góralski, Częstochowa 1994, s. 145-146; W. Adamczewski, Wokół nowego konkordatu, „Przegląd Powszechny”, 10 (1993) s. 1213. Dnia 6 VII 1974 roku został podpisany w Watykanie protokół uzgodnień o ustanowieniu roboczych kontaktów dwustronnych. Na czele Delegacji Stolicy Apostolskiej do stałych kontaktów z PRL stanął abp Luigi Poggi (zastąpiony w 1986 roku przez abpa Francesco Colasuonno), natomiast na czele polskiej delegacji stanął min. Kazimierz Szablewski (zastąpiony w 1982 roku przez Jerzego Kuberskiego).

${ }^{108}$ A. Dudek Problem normalizacji stosunków miedzy władzami PRL a Kościołem rzymskokatolickim w latach 1970-1972, „Studia Historyczne”, 1 (2001) s. 115-129. 
osławionej sekcji „D” był płk. Tadeusz Grunwald, a pierwszym naczelnikiem płk. Zenon Płatek. Działania sekcji obejmowały m.in. ośmieszanie znanych kapłanów, a posługując się plotką ich dyskredytowanie. Ponadto fabrykowano różnego rodzaju fałszywki, np. o zakupie doktoratu w Rzymie przez ks. Karola Wojtyłę. W ramach akcji instalowano także niektórym kapłanom, np. biskupowi Czesławowi Lewandowskiemu z Włocławka, podsłuchy. W czasie pielgrzymek oficerowie podrzucali materiały pornograficzne, kradli plecaki, brudzili śpiwory, przebijali opony w samochodach wiozących rzeczy pielgrzymów. W czasie postojów podtruwali młodych ludzi środkami odurzającymi i wsypywali do pożywienia małe dawki różnych trucizn. Niektórych księży nękali telefonicznymi pogróżkami ${ }^{109}$.

Ostatni okres 1981-1989 wiąże się z pewnego rodzaju „bankructwem polityki wyznaniowej” państwa, której początek wyznaczył stan wojenny. Kościół wzywał do zachowania spokoju, ponieważ uważał, że Polsce może grozić wojna domowa ${ }^{110}$. W 1981roku zmarł prymas Wyszyński. Jego następcą został abp Józef Glemp. W tym też czasie papież Jan Paweł II odbył trzy kolejne pielgrzymki do Polski $(1979,1983,1987)$ Okres ten naznaczony był morderstwem kapelana Solidarności, ks. Jerzego Popiełuszki (1984) ${ }^{111}$. W 1989 roku dokonano przez tzw. nieznanych sprawców morderstw na księżach Stanisławie Suchowolcu (kapelanie białostockiej Solidarności) ${ }^{112}$, Stefanie Niedzielaku (kapelanie AK i WiN) ${ }^{113}$, Sylwestrze Zychu (działaczu opozycyjnym), Czesławie Białku, jezuicie (trzykrotnie aresztowanym) i Stanisławie Palimące ${ }^{114}$. W tym miejscu nie można też nie wspomnieć o kapelanie Solidarności, ks. Kazimierzu Jancarzu z parafii św. Maksymiliana Marii Kolbego w Mistrzejowicach w Nowej Hucie; zmarł nagle w 1993 ro$\mathrm{ku}^{115}$.

${ }^{109}$ Zaryń, Aparat bezpieczeństwa, s. 115-119; M. Lasota, O raporcie sejmowej komisji poświęconej samodzielnej grupie „D” w MSW, „Biuletyn IPN”, 1 (2003) s. 27-53. W ramach „akcji” funkcjonariusze instalowali podsłuchy w mieszkaniach księży i biskupów oraz wydawali pisma szkalujące duchowieństwo w ramach tzw. opozycji wewnętrznej, jak Ancora, Samoobrona Wiary, czy Nowa Droga.

${ }^{110}$ Kościót w stanie wojennym. Rozmowa z historykiem Antonim Dudkiem, KDW, 85 (2002) s. 756-760.

${ }^{111}$ J. Myszor, Popietuszko Jerzy Alfons (1947-1984), kapłan archidiecezji warszawskiej, w: Leksykon duchowieństwa represjonowanego w PRL, t. 1, s. 228-232. Ks. Niedzielak starał się upamiętnić poległych na Wschodzie, natomiast w stosunku do dwóch pozostałych zastosowano podobny schemat prowokacji, jak w przypadku ks. J. Popiełuszki.

${ }^{112}$ P. Latawiec, Suchowolec Stanistaw (1958-1989), wikariusz parafii Suchowola, w: Leksykon duchowieństwa represjonowanego w PRL, t. 1, s. 270-272.

${ }^{113}$ P. Latawiec, Niedzielak Stefan (1914-1989), prałat, proboszcz parafii Powazki, w: Leksykon duchowieństwa represjonowanego w PRL, t. 1, s. 196-198; G. Majchrzak, Ks. Stefan Niedzielak, w: Opozycja w PRL. Stownik biograficzny 1956-1989, t. 1, Warszawa 2000, s. 259-260.

${ }^{114}$ P. Latawiec, Zych Sylwester (1950-1989), kapłan archidiecezji warszawskiej, w: Leksykon duchowieństwa represjonowanego w PRL, t. 1, s. 330-332; E. Nawrot, Białek Czesław (1920-1984), jezuita, w: Leksykon duchowieństwa represjonowanego w PRL, s. 12-13; R. Gryz, Palimaka Stanistaw (1933-1985), kapłan diecezji kieleckiej, w: Leksykon duchowieństwa represjonowanego w PRL, t. 2, s. 212-213; Żurek, W obliczu śmierci, s. 297; Myszor, Portret zbiorowy, s. 102.

${ }^{115}$ Isakowicz-Zaleski, Księża, s. 58-72 
Przez cały okres komunizmu w Polsce (1944-1989) represje zastosowano wobec 704 księży diecezjalnych i 211 zakonników. Spośród diecezji najbardziej represjonowana była archidiecezja warmińska (88 osób), archidiecezje przemyska i gnieźnieńska (po 43), katowicka (41) oraz diecezja greckokatolicka (57). Ze zgromadzeń zakonnych najbardziej represjonowanymi byli franciszkanie (49), jezuici (31) i salezjanie (12) ${ }^{116}$.

Wzrost autorytetu Kościoła i jego hierarchii dawał się zauważyć w chwilach kryzysów społecznych w latach 1956, 1968, 1970, i 1976, a najbardziej w 1980 roku Jak bardzo ważne było w tych czasach działanie Episkopatu Polski - również na płaszczyźnie społecznej -, świadczy fakt, że gdy ksiądz Prymas skończył 75 lat i złożył na ręce papieża rezygnację ze swoich funkcji kościelnych, władze państwowe prosiły Stolicę Apostolską, aby nie przyjmowała rezygnacji ze względu na dobro kraju.

$\mathrm{W}$ połowie lat $80 . \mathrm{XX}$ w. dokonały się zmiany strukturalne również w samej PZPR $i$ to wbrew założeniom ideologicznym. Na ironię losu zasługuje fakt, że nawet w partii zaczęto dostrzegać wzrost religijności wśród samych członków. I tak w 1986 roku za osoby wierzące deklarowało się aż 66\% członków partii, a w grupie najmłodszych (do 29 lat) nawet 76\%. To zdumiewające, ale 1/3 członków PZPR uznawała krzyż i wizerunek Matki Boskiej za symbole narodowe, do których są najbardziej przywiązani ${ }^{117}$. Wojciech Jaruzelski komentując powyższe dane na posiedzeniu władz PZPR w kwietniu 1987 roku twierdził, że partia niesie ,garb religijności” i choć kilkakrotnie próbowała nawet go zrzucić, jednak okazało się to niemożliwe. Mówił też, że ,nie można być komunistą i siedzieć w kruchcie jednocześnie"'118.

Działania represyjne władz komunistycznych wobec Kościoła, które trwały od zakończenia drugiej wojny światowej do 1989 roku stanowią fragment martyrologii Kościoła katolickiego XX w. W tej walce komunistycznych władz polskich z Kościołem zmieniały się tylko metody i środki, ale istota pozostawała zawsze ta sama - usunąc religię z życia społecznego. W analizie omawianego okresu warto zuwazyć, że to dzięki Kościołowi i jego nieugiętej postawie w walce z komunizmem było możliwe odzyskanie niepodległości w 1989 roku ${ }^{119}$.

${ }^{116}$ Myszor, Portret zbiorowy, s. 106-107.

${ }^{117}$ M. Czerwiński, Religia w ideologii PZPR lat 80, w: Między integracja a komunizmem: spoteczeństwa i kościoły Europy Środkowej. Materiały z międzynarodowej konferencji naukowej, Szczecin 8-9 czerwca 2001, red. K. Kowalczyk, Tuchów 2001, s. 83.

118 Zapis stenograficzny rozmowy Ericha Honeckera z Wojciechem Jaruzelskim 16 września 1987 (fragmenty), w: Polska 1986-1989, t. 3: Dokumenty, red. A. Dudek i A. Friszke, Warszawa 2002, s. 52.

${ }^{119}$ Isakowicz-Zaleski, Księża, s. 24 


\title{
THE CHURCH IN POLAND VECTIMISED BY COMMUNIST AUTHORITIES 1944-1989
}

\begin{abstract}
Summary
After the Second World War, Poland underwent the process of Sovietisation. The entire activity of the new authority was confined to the collectivization of agriculture and the fight with the Church. It is true that in the years 1944-1947 the authorities adopted a relatively liberal policy towards the Church, which did not exclude, however, repression against clandestine activities of the clergy, and even assassinations. Soon, an open dispute arose between the authorities and the Episcopate, which was caused, among other things, by the cancellation of the concordat, the decree establishing the obligation of civil marriages and authorities' interference in the church administration on the Recovered Territories (Western and Northern part of Poland). The communist authorities denounced the Catholic clergy for pathological hostility towards communism and post-war reality. Without good reason, they accused the Church of using the pulpit and confessional in this fight and supporting anti-communist underground. The period of severe repression against the Church lasted in the years 1948-1955 . It was the period of arrests, trials and bishops' removal from their dioceses. To fight with the Church, the authorities created a separate Department IV in the Ministry of Home Affairs, whose structure survived until the fall of the Communism. The whole clergy was under control. Their activities were documented in the files of the operational records; from 1963 each clerical student joining the seminary had his file. The authorities also restricted the activities of the Catholic University of Lublin and created the Academy of Catholic Theology from the departments in Krakow and Warsaw. In addition, seminarists were obliged to do military service, the aim of which was to disorganize the teaching at the seminary. To settle the conflict in relations between the state and the Church, the Mixed Commission was established at the initiative of. Its purpose was to resolve conflict issues. In fact, despite the signed agreement, the communist authorities did not keep their commitments from the beginning. They started subversive activities in the Church, forming the movement of the "patriotic priests" attached to The Society of Fighters for Freedom and Democracy. They were given, among other things, the stolen property of the charitable church organization "Caritas".

Throughout the whole period of the Communism in Poland (1944-1989) the authorities used repression against 704 diocesan priests and 211 monks. Repressive measures of the Communists against the Church, which lasted from the end of the Second World War to 1989, are part of the martyrdom of the Catholic Church in the 20th century. In the following years only the methods and means changed in the fight with the Church, the essence remained always the same-to remove religion from public life.
\end{abstract}

